\title{
Struggling with long-time low uptake of modern contraceptives in Pakistan
}

Nasim Zahid Shah, ${ }^{1}$ Tazeen Ali, ${ }^{2}$ Imtiaz Jehan ${ }^{3}$ and Xaher Gul ${ }^{4}$

${ }^{1}$ Center of Excellence Women and Child Health, Aga Khan University, Karachi, Pakistan. ${ }^{2}$ School of Nursing and Midwifery and Community Health Sciences Aga Khan University, Karachi, Pakistan. ${ }^{3}$ Community Health Sciences, Aga Khan University, Karachi, Pakistan. ${ }^{4}$ Technical Services Department Marie Stope Society, Karachi, Pakistan. (Correspondence to: Nasim Zahid Shah: nasim.zahid@aku.edu).

\begin{abstract}
Background: Efforts to expand access to reproductive health care in Pakistan date as far back as the early 1950s. Despite such efforts, the fertility rate has declined at a slower pace compared to that in neighbouring countries.

Aims: To explore the underlying reasons and challenges for long-time low contraceptive use among female clients and key service providers of community-based family planning programmes in Pakistan.

Methods: A qualitative study was carried out with a total of 10 focus group discussions and 7 in-depth interviews with female clients and key service providers. The data were analysed using qualitative content analysis.

Results: The intra-family dynamics, that is, influence of husbands and mothers-in-law, were significant in shaping the decision-making and choice of family planning methods. In addition, inadequate counselling skills, insufficient training for service providers, weak supportive supervision, interrupted supply of contraceptives, and delays in salary disbursement were among the key family planning programme challenges.

Conclusion: Despite a well-designed community-based FP programme, providers' counselling skills need to be enhanced. However, this has to be combined with sufficient training, supportive supervision and contraceptive availability.

Keywords: lady health worker programme, family planning, contraceptives, sexual health, reproductive health

Citation: Shah NZ; Ali TS; Jehan I; Gul X. Struggling with Long-time issue of low uptake of modern contraceptives in Pakistan. East Mediterr Health J. 2020;26(3):297-303. https://doi.org/10.26719/emhj.19.043

Received: 06/01/18; accepted: 04/07/18

Copyright $($ World Health Organization (WHO) 2020. Open Access. Some rights reserved. This work is available under the CC BY-NC-SA 3.0 IGO license (https://creativecommons.org/licenses/by-nc-sa/3.o/igo).
\end{abstract}

\section{Introduction}

On average, women in low- and middle-income countries have more pregnancies than women in high-income countries have, therefore increasing their lifetime risk of death due to pregnancy-related complications (1). An estimated 303000 women lost their lives during and following pregnancy and childbirth in 2015 and one third of these deaths were reported in South Asia (2). This statistic reflects disparities in access to reproductive health care (RHC) - considered an essential human right - among low- and middle-income countries and is possibly due to inadequate RHC provision or underutilization (3).

In order to reduce this rate of maternal mortality, the Safe Motherhood Initiative (a primary component of RHC) has identified family planning (FP) as 1 of the 4 pillars of the initiative, along with antenatal care, postnatal care and safe delivery (4). Family planning is a substantive and effective primary prevention strategy for reducing maternal mortality by decreasing chances of unwanted pregnancies, lowering fertility (5-8) and lowering exposure to pregnancy-associated complications, thereby improving overall RHC (4). As part of FP, the use of contraceptives is considered a cost-effective developmental intervention to accelerate progress across 5 Sustainable Development Goals (SDGs) (9). Despite an increasingly well-recognized and far-reaching impact of FP, the use of modern contraceptives remains low in many low- and middleincome countries, including Pakistan (10).

The current population of Pakistan is 184.5 million and has an annual growth rate of $2 \%$; it is projected that by 2050 , Pakistan will become the fifth most populous country in the world (11). Despite 6 decades of government and private sector RHC initiatives, Pakistan has one of the highest fertility rates and lowest contraceptive use rates among all of its neighbours (12). The average contraceptive prevalence rate (CPR) in South Asian countries is 53\% (2013), and Pakistan has the lowest rate at 35\% (Table 1) (13).

The provision of family planning services and counselling to clients is a major task assigned to lady health workers (LHWs) of the National Programme for Family Planning and Primary Health Care commonly known as the Lady Health Worker Programme (LHWP), and is the largest community-based public sector RHC initiative serving $60-70 \%$ of women in remote and rural populations (14). The recent fourth external evaluation (Oxford Policy Management 2009) of the programme has, however, identified only marginal improvement (33$34 \%$ ) in CPR across the country, having increased only by 1\% (15). Figures from the current Pakistan Demographic Health Survey 2012-2013 indicate that knowledge about FP among women of reproductive age remains universal, that is, $99 \%$, with a slight increase of CPR from 30 to $35 \%$. The overall demand for FP is $70 \%$ with persistent unmet need. Although the Pakistani Government remains the 
major provider of contraceptive methods, only $10 \%$ of users obtain their contraception from LHWs (11).

Progress towards accomplishing Millennium Development Goals (MDGs) to increase CPR to $55 \%$ by 2015 remained unachievable for Pakistan. Given this context of modest increase in CPR and high fertility rate in Pakistan, this study explored the reasons for low utilization of modern contraceptives among both end users and service providers [LHWs and lady health supervisors (LHSs)] of the LHWP, and suggested feasible strategies to overcome the issues identified.

\section{Methods}

\section{Study design and setting}

This qualitative study was carried out from July to September 2013 in urban settings of Korangi District in Karachi. With $\sim 20$ million inhabitants, Karachi is the largest and most populous metropolitan city in Pakistan (16). The study participants were selected through purposive sampling from Korangi and Shah Faisal Towns, which are covered by the LHWP.

\section{Study participants and data collection}

The study participants were divided into 2 groups: (1) registered married women of reproductive age (15-45 years) residing in the study area for $>1$ year and seeking FP services from the LHWP; and (2) LHSs and LHWs who have been working under the LHWP for $>1$ year and providing FP services in the study area. The data were collected mainly through 3 Focus Group Discussions (FGDs) with registered women, 7 FGDs with LHWs and 7 in-depth interviews (IDIs) with LHSs. The interviews lasted for 4560 minutes and each FGD comprised 6-8 participants.

\section{Data analysis}

The discussions were audio recorded, then transcribed verbatim for qualitative content analysis. The codes were grouped into categories and similar categories were finally merged leading to main themes.

\section{Ethical considerations}

Ethical approval for the study was granted by the Ethical Review Committee of the Aga Khan University, Karachi, and provincial and district programme implementation units of the LHWP.

\section{Results}

The results of our qualitative study fell under two major themes: (1) low uptake of modern contraceptives from the female perspective; and (2) understanding the reasons for low uptake of modern contraceptives from the service providers' point of view.

\section{Low uptake of modern contraceptives from the female perspective}

Most FP clients reported a positive impression about the use of temporary methods of contraception. They are

\begin{tabular}{lccc}
\hline $\begin{array}{l}\text { Table } 1 \text { Fertility rate, CPR and MMR comparison among } \\
\text { South Asian countries }\end{array}$ & $\begin{array}{c}\text { Fertility } \\
\text { rate }\end{array}$ & CPR \% & $\begin{array}{c}\text { MMR/100 } \\
\text { Coon }\end{array}$ \\
\hline Pakistan & 3.2 & 35 & 260 \\
Maldives & 2.3 & 35 & 60 \\
Nepal & 2.3 & 50 & 170 \\
Bangladesh & 2.2 & 62 & 240 \\
India & 2.5 & 55 & 200 \\
Sri Lanka & 2.3 & 68 & 35 \\
Islamic Republic of Iran & 1.9 & 77 & 21 \\
\hline
\end{tabular}

Source: World Health Indicators 2015. World Bank, Washington DC. CPR = contraceptive prevalence rate; $M M R=$ maternal mortality ratio

more inclined towards use of condoms as the preferred choice, mainly because they describe them as easy to use, readily available, having fewer side effects, and satisfying their partner. The use of other temporary methods reported by the clients include injections, pills and intrauterine contraceptive devices.

"We use condoms. There are many benefits with them and no side effects. There is nothing bad. My health is good and my husband's health is also good."

Fear of side effects of contraceptives is reported as a challenge by female clients and may cause them to discontinue their use or switch to other methods with fewer side effects. The main side effects as mentioned by the clients included menstrual irregularities, palpitations, headaches, and weight gain.

"Initially I was taking pills, and then I developed problems like palpitations, headache, nausea and stomach upset. I did not find pills comfortable to use and therefore stopped. Since then, I have used condoms and I feel satisfied, and my husband is also happy."

Spousal approval was reported as significant in determining the use of contraceptives, as emphasized by female clients. It was mainly due to lack of approval or willingness of husbands that women faced difficulty, despite their need. Besides spousal agreement and willingness, the influence of mothers-in-law was described as another social barrier affecting the family planning decision-making process. This influence was reported more in families where the husband was the only child and where more female children were born.

"My sister-in-law is not using family planning because her husband is not willing to use it. At present she has 5 children including 1 male child. The husband has a desire for more sons. To fulfil his desire, she already gave birth to 4 daughters."

"I am a mother of 6, every child born with a gap of 1.5 years. My husband is the only son and my mother-in-law forces me not to take any tablets or anything related to FP. She keeps a close watch." 


\section{Understanding reasons for low uptake of modern contraceptives from the perspective of service providers}

\section{Communitylevel}

Similar to the accounts of female clients, those of service providers (LHWs and LHSs) also revealed a high uptake of condoms (despite high failure rates) followed by pills and injections. They described condoms as safe, easy to use and with the added advantage of providing protection from sexually transmitted diseases. Also, at the household level, as explained by female clients, the influence of the husband and mother-in-law was considered significant in shaping family planning decision-making by couples. In most instances it was the wife who was struggling hard for FP, while the husband seemed less motivated. It was because of the lack of agreement and involvement of the husband that some of the women even used contraceptives without the knowledge of their husband and mother-in-law. Furthermore, in certain tribes the mother-in-law still believed in large families and wished her son to follow in the same manner.

"The cooperation and willingness of husbands is important for successful practice of family planning. The husband is rigid and difficult to deal with at times, and in that situation women face problems. If the husband is cooperative then it becomes easier for wives to practice family planning."

"I visit 2 of my clients when the mothers-in-law are away from home. Because the mothers-in-law do not want them [daughters-in-law] to use contraception."

The service providers emphasized counselling to family planning clients as a major task assigned to LHWs but in practice counselling was not provided to couples, but involved female clients only. In a society less open to talk about issues like family planning, the service providers described it as difficult to provide counselling to men. However, they stressed effective engagement of men during counselling and decision-making because men require more awareness of their role for better uptake of contraceptives. The sehat (health) committee at village level included male members, but their primary focus was on general health issues. The service providers stressed that in, addition to creating awareness on primary health issues, they should also address issues like FP, especially for men.

"Similarly, male members of the sehat committee should work with us. They may conduct continuous meeting with husbands or at least once a month to create awareness for FP. This will be helpful in counselling men as we mostly counsel women but not men."

\section{Revisions in curriculum and refresher training}

The participants mentioned that there were instances when the LHWs felt less capable to satisfy clients. For example, when the clients enquired more information about FP than the LHWs had already shared. To be more confident and able to satisfy clients, participants urged revisions to existing curricula, with inclusion of recent research and methods along with locally appropriate communication strategies to enhance knowledge and counselling skills of LHWs, focusing on creating more awareness among men regarding use and benefits of family planning. They further expressed their dissatisfaction on frequency and quality of training sessions being held. Generally, LHSs conducted classroom sessions with the purpose of revision of certain topics. Since LHSs have limited information, qualification and skills, it was suggested to involve qualified trainers for conducting training for LHWs and LHSs.

"I think in this changing context, the current curriculum is not sufficient for us as we have confined our clients mostly to condom use only."

"Our curriculum needs revision with updated information and new research. The focus should be on providing adequate knowledge/information to men and women and motivating clients to use family planning."

"I joined the programme in 1994 and received training from trainers who were experts in the field. They taught us everything in such a way that we became 'half doctors'. If frequent and expert training is done, we can achieve 90-95\% positive results."

\section{Inadequate supervision and oversight}

Generally, LHWs agreed that LHSs are supportive, while few mentioned that LHWP should discourage induction of young LHSs with less field experience. For better performance of LHWs, the LHSs should also be evaluated on a regular basis for their supervisory and monitoring skills. Previously, the district and regional coordinators of the programme used to have field visits, but the current programme structure lacked a regular system for supportive supervision of LHSs. If included, this would encourage service providers to execute quality work, with increased sense of responsibility and accountability.

"If LHSs think that they may have surprise visits from higher authorities, then they [LHS] will deliver the job with more sense of accountability and responsibility. In this way, they will be held answerable for performance of their LHWs."

\section{Supply shortages and failures}

Nonavailability of medicines,family planning supplies and stationary items was reported as a chronic issue in the past few years, and frequent medicine and supply failures were reported by most of the LHWs. The most commonly used contraceptives were condoms, but LHWs stressed that the quantity of condoms provided was insufficient to meet demand. This has resulted in increased pregnancies, for which the community blamed LHWs.

"The supplies are not sufficient for the whole community. For example, we get a low supply of condoms. If we can just have 
a proper supply of condoms only, this will help us a lot."

\section{Overall low motivation level of LHWs and LHSs}

Frequent delays in salary disbursement and low job security were the main reasons reported for demotivation and eventually underperformance by LHWs and LHSs. It was difficult to meet household expenses with such low and frequently delayed incentives, especially for those who were sole bread winners (widows or divorced). Even after the decision by the authorities to make LHWs a permanent cadre, the service providers were still waiting for implementation of the orders.

"It was in 2012 when the Court declared LHWs as a permanent cadre with increased salary, to be paid with arrears. However, to date, we do not have written proof of whether we are permanent or not. The Court's orders should be carried out quickly as there is no implementation on the ground."

\section{Discussion}

There is a great sense of encouragement demonstrated by female clients towards use of contraceptives. Regardless of fear of side effects and other barriers, they are still inclined to practice family planning. In contrast, despite having a country-wide family planning programme, the intra-family dynamics (influence of husband and mother-in-law) are acknowledged as significant in shaping the decision-making and choice of family planning methods. The opportunity to discuss the use of contraceptives with their husband not only empowers wives but also affects maternal and child health outcomes in the long run. Therefore, spousal concordance and communication are key for effective uptake of contraceptives - a finding supported by existing literature (17-21).

The influence of the mother-in-law is still voiced as a challenge at the household level. The underlying reason is considered to be rooted in different mind sets within the family dynamics such as: (1) mothers-in-law who were less inclined to use family planning themselves tend to influence their sons and daughters-in-law to do likewise; (2) if the husband is the only son; and (3) families in which there is a desire for a son due to the birth of more daughters. Our findings are consistent with previous studies in Pakistan and neighbouring countries $(22,23)$.

Counselling is one of the key components of the FP programme and affects the knowledge, use and spousal communication for use of contraceptives $(24,25)$. Although counselling is reported to be the major task performed by LHWs, it is only for female clients without involvement of their husbands. Male engagement in counselling is an area not effectively addressed by the current programme structure. It can be ensured through revitalization and involvement of male members of existing health committees, and by conducting awareness sessions for men regarding family planning. This significant finding is supported by available evidence from other low- and middle-income countries $(26,27)$ where male engagement in counselling increases uptake of contraceptives by creating awareness of methods, services $(28,29)$ and improving spousal communication for method preference $(30,31)$. In comparison to no counselling, couple counselling reported a 54\% increase in uptake of contraceptives in a recent randomized control trial conducted in another Muslim country, Jordan (28).

Insufficient curricular revisions and trainings to service providers, weak supportive supervision, interrupted flow of FP commodities and delayed salary disbursements are other key programme areas not sufficiently addressed by the LHWP. These findings are supported by a recent external evaluation of the LHWP, which highlighted key programme impediments to be seriously addressed (32). Despite the current low strength of LHWs, there is a significant community acceptance of LHWs since they have demonstrated potential to deliver services.

Therefore, appropriate curricular revision, shifting from theory to a more practical approach and addition of effective interpersonal communication skills can better equip service providers for counselling clients. In-service training and professional development are important contributors towards maintenance of competencies for delivery of quality services by community workers, especially in low- and middle-income countries (33). This can be achieved with appropriate modifications to delivery and design of in-service training with revisions to curricula, and overall assessment of performance $(14,33)$. Simultaneously, effective supervision by LHSs through improved skills assessment, feedback and reinforced regular supervisory visits, along with good district management practices for timely availability of supplies and salaries, are important for improving overall productivity of service providers and hence uptake of modern contraceptives. When supply of essential commodities is disrupted, not only will the productivity of LHWs decrease, but there may be other consequences such as losing respect from the community, without which the desired tasks cannot be executed.

The criteria of Lincoln and Guba were followed in order to achieve trustworthiness of the study (34). Credibility was obtained by selection of appropriate participants, context, interview guides for FGDs and IDIs, and by choosing representative quotations from the transcriptions. Dependability was assured by conducting the FGDs and IDIs over a period of 1 month, so that phenomena under study would not change in the communities. All the FGDs and IDIs were conducted in the local language and moderated by researchers well versed in language and context. Conformability was achieved by separate coding of teams followed by discussion on similarities and dissimilarities.

Our analysis suggests a comprehensive and integrated approach involving individual, community and management level stakeholders in order to address the challenges identified by the study participants, for enhanced uptake of modern contraceptives in the LHWP.

The LHWs play a pivotal role in the healthcare system in 
Pakistan. There is strong potential to enhance counselling and interpersonal communication skills of LHWs and LHSs - a major contributing factor for acceptance and practice of family planning. It is the basic right of couples to decide freely the number and birth spacing of their children. Thus, effective counselling and communication are the way to provide adequate information, education and the means to do so.

Since family planning/birth-spacing choices are more often decided by couples rather than women alone, revitalization of the health committees at community level is strongly needed to promote effective male engagement in RHC initiatives designed to improve women and child health and particularly family planning services. Integrated and well-targeted behavioural change communication activities and community mobilization/ awareness campaigns can help address sociocultural issues and misconceptions about contraceptive use. This has a considerable positive impact on awareness and acceptability of family planning among community members as part of efforts to create demand. Moreover, the involvement of relevant stakeholders, such as community leaders, religious clerics and health activists in the health committees and various behavioural change communication modalities, will lead to substantial community ownership.

The above has to be combined with strategies to strengthen the existing programme structure, such as adequate and periodic needs-based assessment of LHWs and LHSs, sufficient training, and effective supportive supervision (both technical and supervisory) of LHSs. Furthermore, giving greater financial control to district health departments with oversight by provincial level stakeholders could potentially improve availability of funds for salaries, supplies and stationary. Lastly, a significant period of time has elapsed since the last evaluation (32), therefore, re-evaluation of the LHWP may be carried out in order to track the progress and shortcomings.

\section{Acknowledgment}

We thank the Provincial and District Programme Implementation Units of the LHWP in Hyderabad and Karachi, and the participants of this study for their valuable time and contribution.

Funding: None.

Competing interests: None declared.

\section{Difficultés liées à la faible utilisation prolongée des méthodes de contraception modernes au Pakistan}

\section{Résumé}

Contexte : Les efforts pour élargir l'accès aux soins de santé génésique au Pakistan remontent au début des années 1950. En dépit de ces efforts, le taux de fécondité a baissé à un rythme plus lent que celui des pays voisins.

Objectifs : Étudier les raisons et les difficultés sous-jacentes expliquant la faible utilisation prolongée des contraceptifs par les clientes et les principaux prestataires des programmes de planification familiale à base communautaire.

Méthodes : Une étude qualitative a été réalisée au moyen d'un total de dix discussions thématiques de groupe et de sept entretiens approfondis avec des clientes et les principaux prestataires de services. Les données ont été analysées en utilisant une analyse de contenu qualitative.

Résultats : Les dynamiques intrafamiliales, à savoir l'influence des maris et des belles-mères, jouaient un rôle déterminant dans la prise de décision et le choix relatifs aux méthodes de planification familiale. De plus, les compétences de conseil inadéquates, la formation insuffisante des prestataires de services, le faible degré d'encadrement bienveillant, l'interruption de l'approvisionnement en contraceptifs et les retards dans le versement des salaires faisaient partie des principales difficultés liées aux programmes de planification familiale.

Conclusions : Malgré un programme de planification familiale à base communautaire bien pensé, les compétences de conseil des prestataires doivent être améliorées. En outre, il importe qu'elles soient associées à une formation adéquate, un encadrement bienveillant et une meilleure disponibilité des contraceptifs.

$$
\begin{aligned}
& \text { مكافحة انخفاض استعمال وسائل منع الحمل الحديثة فترةً طويلةً في باكستان } \\
& \text { نسيم زاهد شاه، تزين علي، امتياز جيهان، زاهر جول } \\
& \text { الخلاصة } \\
& \text { الخلفية: تعود جهود التوسع في إتاحة الرعاية الصحية الإنجابية في باكستان إلى أوائل الخمسينيات من القرن الماضي. وعلى الرغم من هذه الجهوده، }
\end{aligned}
$$

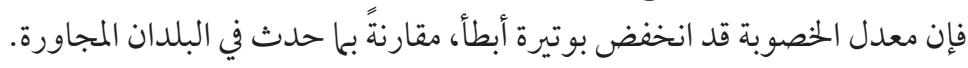




$$
\begin{aligned}
& \text { الأهداف: هدفت الدراسة إلى استكشاف الأسباب والتحديات المتعلقة بانخفاض استعحال وسائل منع الحمل فترةً طويلةً على مستوى العملاء }
\end{aligned}
$$

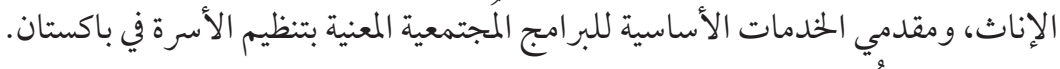

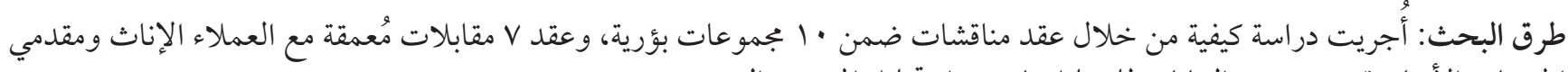

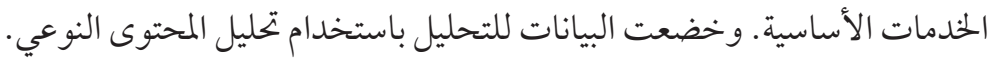

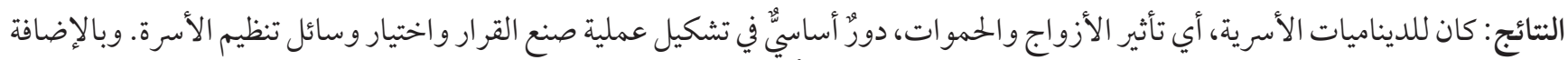

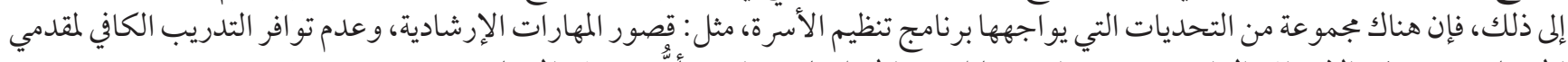

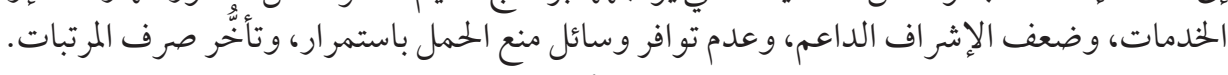

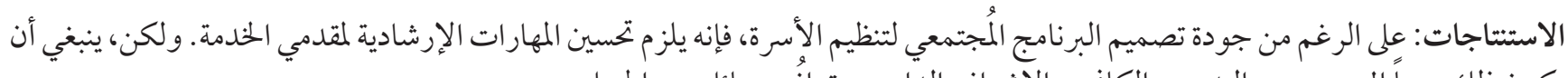

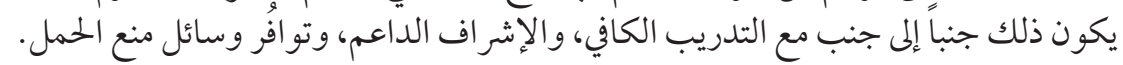

\section{References}

1. Trends in maternal mortality: 1990 to 2013: estimates by WHO, UNICEF, UNFPA, The World Bank and the United Nations Population Division. Geneva: World Health Organization; 2014 (https://apps.who.int/iris/bitstream/handle/10665/112682/9789241507226_eng.pdf;jsessionid=5EE560E74DFC18530AB084F245CC773B?sequence=2, accessed 21 August 2019).

2. Alkema L, Chou D, Hogan D, Zhang S, Moller AB, Gemmill A et al. Global, regional, and national levels and trends in maternal mortality between 1990 and 2015, with scenario-based projections to 2030: a systematic analysis by the UN Maternal Mortality Estimation Inter-Agency Group. Lancet. 2016 Jan 30;387(10017):462-74. http://dx.doi.org/10.1016/So140-6736(15)00836-7 PMID:26584737

3. Programme of Action: adopted at the International Conference on Population and Development, Cairo, 5-13 September 1994. United Nations Population Fund; 2004 (https://www.unfpa.org/sites/default/files/event-pdf/PoA_en.pdf, accessed 21 August 2019).

4. Ahmed S, Li Q, Liu L, et al. Maternal deaths averted by contraceptive use: an analysis of 172 countries. Lancet. 2012 Jul 14;380(9837):111-25. http://dx.doi.org/10.1016/So140-6736(12)6478-4 PMID:22784531

5. Bongaarts J. Slow down population growth: within a decade, women everywhere should have access to quality contraceptive services. Nature. 2016 Feb 25;530(7591):409-13. http://dx.doi.org/10.1038/530409a PMID:26911766

6. Westoff CF. The recent fertility transition in Rwanda. Population Dev Rev. 2012;38(Suppl):169-78.

7. Bongaarts J. The impact of family planning programs on unmet need and demand for contraception. Stud Fam Plan. 2014 Jun;45(2):247-62. http://dx.doi.org/10.1111/j.1728-4465.2014.00387.x PMID:24931078

8. Brown W, Ahmed S, Roche N, Sonneveldt E, Darmstadt GL. Impact of family planning programs in reducing high-risk births due to younger and older maternal age, short birth intervals, and high parity. Semin Perinatol. 2015 Aug;39(5):338-44. http://dx.doi. org/10.1053/j.semperi.2015.06.006 PMID:26169538

9. Starbird E, Norton M, Marcus R. Investing in family planning: key to achieving the sustainable development goals. Glob Health Sci Pract. 2016 Jun 27;4(2):191-210. http://dx.doi.org/10.9745/GHSP-D-15-00374 PMID:27353614

10. Sedgh G, Ashford LS, Hussain R. Unmet need for contraception in developing countries: examining women's reasons for not using a method, New York: Guttmacher Institute; 2016 (http://www.guttmacher.org/report/unmet-need-for-contraception-in-developing-countries, accessed 21 August 2019).

11. National Institute of Population Studies (NIPS) [Pakistan] and ICF International. 2013. Pakistan Demographic and Health Survey 2012-13. Islamabad: National Institute of Population Studies, and Calverton, MD: ICF International; 2013 (https://dhsprogram. com/pubs/pdf/fr290/fr290.pdf, accessed 21 August 2019).

12. Khan AA, Khan A, Javed W, Hamza HB, Orakzai M, Ansari A et al. Family planning in Pakistan: applying what we have learned. J Pak Med Assoc. 2013 Apr;63(4 Suppl 3):S3-10. PMID:24386723

13. The little data book 2015. Washington, DC: World Bank; 2015 (http://documents.worldbank.org/curated/en/752941468322436073/ pdf/95786oPUB0978100Box385458BooPUBLICo.pdf, accessed 21 August 2019).

14. Rabbani F, Mukhi AAA, Perveen S, Gul X, Iqbal SP, Qazi SA et al. Improving community case management of diarrhoea and pneumonia in district Badin, Pakistan through a cluster randomised study - the NIGRAAN trial protocol. Implement Sci. 2014 Dec 10;9:186. http://dx.doi.org/10.1186/s13012-014-0186-9 PMID:2549097

15. External evaluation of the national program for family planning and primary health care: Lady Health Worker Program. Summary of results. Oxford Policy Management; 2009 (https://www.opml.co.uk/files/Publications/6241-evaluating-lady-health-worker-programme/lhw-4th-evaluation-summary-of-results.pdf?noredirect=1, accessed 21 August 2019).

16. Official web portal of Karachi Metropolitan Corporation [website]. Karachi Metropolitan Corporation; $2011-2012$ (http://www. kmc.gos.pk/Contents.aspx?id=84, accessed 22 August 2019). 
17. Hameed W, Azmat SK, Ali M, Sheikh MI, Abbas G, Temmerman M et al. Women's empowerment and contraceptive use: the role of independent versus couples' decision-making, from a lower middle income country perspective. PloS One. 2014 Aug 13;9(8):e104633. http://dx.doi.org/10.1371/journal.pone.0104633 PMID:25119727

18. Raj A, Ghule M, Ritter J, Battala M, Gajanan V, Nair S et al. Cluster randomized controlled trial evaluation of a gender equity and family planning intervention for married men and couples in rural India. PloS One. 2016 May 11;11(5):e0153190. http://dx.doi. org/10.1371/journal.pone.0153190 PMID:27167981

19. Ling JES, Tong SF. The roles of men in family planning - a study of married men at the UKM primary care clinic. Malays Fam Physician. 2017 Apr 30;12(1):2-13. PMID:28503268

20. Tilahun T, Coene G, Temmerman M, et al. Spousal discordance on fertility preference and its effect on contraceptive practice among married couples in Jimma zone, Ethiopia. Reprod Health. 2014 Apr 4;11(1):27. http://dx.doi.org/10.1186/1742-4755-11-27 PMID:24708827

21. Mboane R, Bhatta MP. Influence of a husband's healthcare decision making role on a woman's intention to use contraceptives among Mozambican women. Reprod Health. 2015 Apr 23;12(1):36. http://dx.doi.org/10.1186/s12978-015-0010-2 PMID:5902830

22. Mustafa G, Azmat SK, Hameed W, Ali S, Ishaque M, Hussain W et al. Family planning knowledge, attitudes, and practices among married men and women in rural areas of Pakistan: findings from a qualitative need assessment study. Int J Reprod Med. 2015; Article ID 190520. http://dx.doi.org/10.1155/2015/190520

23. Char A, Saavala M, Kulmala T. Influence of mothers-in-law on young couples' family planning decisions in rural India. Reprod Health Matters. 2010 May;18(35):154-62. http://dx.doi.org/10.1016/So968-8080(10)35497-8 PMID:20541094

24. Bellizzi S, Sobel HL, Obara H, Temmerman M. Underuse of modern methods of contraception: underlying causes and consequent undesired pregnancies in 35 low-and middle-income countries. Hum Reprod. 2015 Apr;30(4):973-86. http://dx.doi. org/10.1093/humrep/deu348 PMID:25650409

25. Huda FA, Chowdhuri S, Sirajuddin MFR. Importance of appropriate counselling in reducing early discontinuation of Norplant in a northern district of Bangladesh. J Health Popul Nutr. 2014 Mar;32(1):142. PMID:24847603

26. Mosha I, Ruben R, Kakoko D. Family planning decisions, perceptions and gender dynamics among couples in Mwanza, Tanzania: a qualitative study. BMC Public Health. 2013 May 30;13(1):523. http://dx.doi.org/10.1186/1471-2458-13-523 PMID:23721196

27. Aransiola JO, Akinyemi AI, Fatusi AO. Women's perceptions and reflections of male partners and couple dynamics in family planning adoption in selected urban slums in Nigeria: a qualitative exploration. BMC Public Health 2014 Aug 23;14:869. http:// dx.doi.org/10.1186/1471-2458-14-869 PMID:25148699

28. El $\triangle$ Khoury M, Thornton R, Chatterji M, et al. Counseling Women and Couples on Family Planning: A Randomized Study in Jordan. Stud Fam Plann. 2016 Sep;47(3):222-38. http://dx.doi.org/10.1111/sifp.69 PMID:27611319

29. Shattuck D, Kerner B, Gilles K, Hartmann M, Ng'ombe T, Guest G. Encouraging contraceptive uptake by motivating men to communicate about family planning: the Malawi Male Motivator project. Am J Public Health. 2011 Jun;101(6):1089-95. http:// dx.doi.org/10.2105/AJPH.2010.300091 PMID:21493931

30. Hartmann M, Gilles K, Shattuck D, et al. Changes in couples' communication as a result of a male-involvement family planning intervention. J Health Commun. 2012 Aug;17(7):802-19. http://dx.doi.org/10.1080/10810730.2011.650825 PMID:22545820

31. His and her fertility preferences: an experimental evaluation of asymmetric information in family planning. 2015 Oct 22. http:// thew.web.unc.edu/files/2013/08/mccarthy.pdf

32. External evaluation of the National Program for Family Planning and Primary Health Care: Lady Health Worker Programme: systems review. Oxford Policy Management; 2009 (https://www.opml.co.uk/files/Publications/6241-evaluating-lady-health-worker-programme/lhw-systems-review.pdf?noredirect=1, accessed 22 August 2019).

33. Bennibor S, Ngobua S, Bailey R, Alozie A, Eton J, Puckett A. Report of training needs assessment for commuinty health workers in South-South Geopolitical Region of Nigeria. USAID, Capacity Plus; 2014 (https://www.capacityplus.org/files/resources/report-training-needs-assessment-nigeria.pdf, accessed 22 August 2019).

34. Graneheim UH, Lundman B. Qualitative content analysis in nursing research: concepts, procedures and measures to achieve trustworthiness. Nurse Educ Today. 2004 Feb;24(2):105-12. http://dx.doi.org/10.1016/j.nedt.2003.10.001 PMID:14769454 